\title{
THE EFFECT OF VARIOUS COPPER SOURCES ON THE TRACE ELEMENTS PROFILE IN THE HAIR, PLASMA AND FAECES AND COPPER ACTIVITY IN THE ORGANISM OF HORSES
}

\author{
P. Jančíková, P. Horký, L. Zeman
}

Received: June 29, 2012

\begin{abstract}
JANČÍKOVÁ, P., HORKÝ, P., ZEMAN, L.: The effect of various copper sources on the trace elements profile in the hair, plasma and faeces and copper activity in the organism of horses. Acta univ. agric. et silvic. Mendel. Brun., 2012, LX, No. 6, pp. 145-152

In our experiment with 20 mares (3.6-19.8 years old) divided into 3 groups we evaluated the effect of supplementation with various sources of copper on the trace elements profile in the hair, blood plasma and faeces and copper activity in the organism of horses. The horses were stabled in box stalls (similar dimension) with feeding pump, with the access to a paddock or walker. All mares received the same basic feed ration that was supplemented with various form of copper ( $\mathrm{Cu}$ in the organic form proteinate - Bioplex $\mathrm{Cu}$ vs. $\mathrm{Cu}$ in the inorganic form - $\mathrm{CuSO}_{4} .5 \mathrm{H}_{2} \mathrm{O}$ ) in amount of $120 \mathrm{mg}$ per day for the mares in experimental groups. The contents of trace elements in hair and faeces were established using the atomic absorption spectrometry; in the plasma using direct colorimetric determination. Significant difference between mares receiving copper in organic and inorganic form $(\mathrm{P}<0.05)$ was detected in the blood levels of copper and iron. In both experimental groups a supplement of copper increased its level in the hair as compared to the control group; however this increase was statistically significant $(\mathrm{P}<0.01)$ only if the inorganic form of copper was supplemented. The iron content of mares hair apparently varied not only with minerals intake, but also with the condition of kept. The differences of copper concentration in the faeces among the mares of experimental groups with regard to control group were significant $(\mathrm{P}<0.01)$. An excessive amount of copper evidently reduced the absorption of zinc and iron in mares with addition of copper sulphate.

The mares receiving Bioplex-Cu excreted lower amount of copper in the faeces. These had wellbalanced levels of $\mathrm{Cu}$ in the plasma and deposited less $\mathrm{Cu}$ in the hair than the mares with addition of copper sulphate. In our experiment, it seems to be better available copper in the organic form than in the inorganic form for the organism of horses.

Nevertheless, interpretation of these results is very difficult. Evaluation the impact of various sources of copper on the elements profile; assessed using skin derivates, plasma or other parameters should be subjected to further observation.
\end{abstract}

horse, copper sulphate, copper bioplex, hair, faeces, blood plasma

Elemental $\mathrm{Cu}$ is commonly added to formulated horse diets to correct or prevent deficiencies and related disorders. Mineral supplements can be divided into 2 groups: inorganic salts, typically including a sulphate or oxide group, and organic chelates, where the mineral is covalently bound to an amino acid or proteinate complex. Organic chelate minerals require fewer steps to be absorbed, making the process more efficient compared with the inorganic mineral salts (Wagner et al., 2011).

Interaction among trace elements may change their efficiency. An excessive amount of one trace element may reduce the absorption or transport of other mineral substances which have a similar form (Hill and Matrone, 1970; cit., Herdt and Hoff, 2011). Among the potential modifiers reducing 
copper absorption in the intestine belongs divalent cations, in particular zinc, iron and molybdenum (Wapnir, 1998; Pagan, 2001). The most of the copper is excreted in the faeces; the digestive tract is also the main mode of zinc excretion (Wapnir, 1998; Hoyt et al., 1995) and the amount of trace elements excreted in the excrements clearly corresponds to the uptake of these elements in the feed (Schryver et al., 1980).

Despite the lack of scientific data to prove reliability, hair analyses has been advertised as a prognostic and diagnostic tests for dietary mineral imbalances in horses (Wells et al., 1990). Research to date indicates that concentrations of certain trace elements in hair may be related to dietary intake (Combs et al., 1982). Dunnett and Lees (2003) likewise used hair as an indicator of the mineral status of the whole body. Minerals incorporated within the follicle reflect the mineral status at the time that the hair filament was synthesised (Combs, 1987). Wells et al. (1990) informed that synergic and antagonistic correlations among mineral elements and their effect on metabolism probably have a greater impact on the content of mineral elements in hair than the actual insufficiency or oversupply of an element. However, there are still uncertainties as to whether hair content is well correlated with whole body levels and the validity of the approach in the horse remains to be confirmed (Hintz, 2001).

Blood samples are frequently analysed to determine the mineral status of the animals (Herdt and Hoff, 2011). However, the blood level of minerals does not often correspond to the content of minerals in the whole body because the composition of plasma results from supplementation of deficiencies by highly efficient homeostatic mechanisms (Radomska et al., 2005; cit., Gabryszuk et al., 2010; Lowe et al., 2009).

The objective of present study was to evaluate trace elements status and activity of copper in the organism after addition of different copper source into feed rations. We expected that activity of organic copper source in organism of horses will be higher than in sulphate form and that an over-supply this element in the diets of mares will be directly related with the changes of monitored parameters.

\section{MATERIALS AND METHOD}

Twenty Bohemian warm-blooded mares were included in the experiment for 14 days. The horses were stabled in box stalls (similar dimension) with feeding pump, with the access to a paddock or walker. The mares of various ages (3.6-19.8 years), similar weight categories $(520-580 \mathrm{~kg}$ ) and light workload were divided into three groups, subjected to different mineral feeding modes (Tab. I).

The mares were fed twice a day by grain mixture (at 7 a. m. and 17 p. m.). Five days before and in the course of the trial, all animals received the same basic feeding ration consisting of ad libitum intake to hay that was measured ( $12.1 \pm 0.93 \mathrm{~kg}$ hay/day), $1.0 \mathrm{~kg}$ of oats, $0.75 \mathrm{~kg}$ of wheat meal and $0.75 \mathrm{~kg}$ of barley meal. Nutrient composition of the feeds is showed in the Tab. II.

I: The characteristic of horses and conditions under which the horses were kept

\begin{tabular}{|c|c|c|c|c|c|c|}
\hline Group & Horses & Age (years) & Colour & $\begin{array}{c}\text { Paddock } \\
\text { (h/day) }\end{array}$ & $\begin{array}{l}\text { Walker (min/ } \\
\text { day) }\end{array}$ & $\begin{array}{c}\text { Daily intake Cu } \\
(\mathrm{mg})\end{array}$ \\
\hline \multirow{7}{*}{$\begin{array}{l}\text { Organic form } \\
\mathrm{Cu} \\
(\mathrm{n}=7)\end{array}$} & 1 & 10.7 & Bay & 8 & - & 195 \\
\hline & 2 & 6.6 & Bay & - & 45 & 195 \\
\hline & 3 & 10.8 & White & - & 45 & 195 \\
\hline & 4 & 5.6 & Bay & - & 45 & 195 \\
\hline & 5 & 8.4 & Bay & - & 45 & 195 \\
\hline & 6 & 5.5 & Bay & 8 & - & 195 \\
\hline & 7 & 8.6 & Chestnut & - & 45 & 195 \\
\hline \multirow{7}{*}{$\begin{array}{l}\text { Inorganic form } \\
\mathrm{Cu} \\
(\mathrm{n}=7)\end{array}$} & 8 & 3.8 & Bay & - & 45 & 195 \\
\hline & 9 & 13.7 & Bay & 8 & - & 195 \\
\hline & 10 & 17.7 & Bay & 8 & - & 195 \\
\hline & 11 & 12.7 & Chestnut & - & 45 & 195 \\
\hline & 12 & 16.6 & Bay & 8 & - & 195 \\
\hline & 13 & 8.3 & Bay & 8 & - & 195 \\
\hline & 14 & 5.8 & Bay & 8 & - & 195 \\
\hline \multirow{6}{*}{$\begin{array}{l}\text { Control } \\
(n=6)\end{array}$} & 15 & 8.8 & Bay & 8 & - & 75 \\
\hline & 16 & 5.7 & Bay & 8 & - & 75 \\
\hline & 17 & 3.6 & White & 8 & - & 75 \\
\hline & 18 & 3.6 & Bay & 8 & - & 75 \\
\hline & 19 & 3.9 & Bay & 8 & - & 75 \\
\hline & 20 & 9.8 & Chestnut & - & 45 & 75 \\
\hline
\end{tabular}


II: Nutrient composition of the feeds making up the basic feed ration for horses

\begin{tabular}{lccc}
\hline & Meadow hay & Oat & Meal* \\
\hline Dry matter (g) & 880.40 & 873.10 & 902.10 \\
\hline Fiber (g) & 303.07 & 102.91 & 20.85 \\
Fat (g) & 21.73 & 42.71 & 19.47 \\
Crude protein (g) & 94.00 & 119.38 & 121.98 \\
Ash (g) & 71.39 & 29.53 & 21.30 \\
Ca (g) & 2.60 & 0.68 & 0.40 \\
Mg (g) & 1.15 & 1.08 & 1.03 \\
Fe (mg) & 157.03 & 93.25 & 60.16 \\
Zn (mg) & 35.10 & 32.06 & 34.83 \\
Cu (mg) & 5.85 & 5.11 & 5.01 \\
\hline
\end{tabular}

* $50 \%$ wheat meal, $50 \%$ barley meal

Horses in the experimental groups received additional copper $(\mathrm{Cu})$ in various forms at level of $120 \mathrm{mg}$ /day with their evening (17 p. m.) grain feed ration. Group named "organic form $\mathrm{Cu}$ " (n = 7) received $\mathrm{Cu}$ in the organic form - proteinate (Bioplex $\mathrm{Cu}$, ALLTECH), while Group "inorganic form $\mathrm{Cu}$ " $(\mathrm{n}=7)$ was fed with $\mathrm{Cu}$ in the inorganic form - $\mathrm{CuSO}_{4} \cdot 5 \mathrm{H}_{2} \mathrm{O}$, and Group "control" $(\mathrm{n}=6)$ received fodder without the $\mathrm{Cu}$ enrichment and was used as a control group. The amount of mineral substances in water was not taken into account. No additional minerals and vitamins were supplied in the diet.

Blood samples for the required analyses were taken on day $1^{\text {st }}$ (initial - before supplementation) and $14^{\text {th }}$ (final - after supplementation) of the trial. The samples were taken at the same time (2 hours after morning feeding); the mares were not physically strained or stressed before the blood sampling. The blood was taken from the vena jugularis externa into plastic samplers with an anticoagulation solution - heparin. Immediately after the collection, the samples were placed in a transport cooling box and not later than within 2 hours they were processed and stored to be used in following analyses. The blood was centrifuged for 20 minutes $(2300 \mathrm{rpm})$ and the resulting plasma was frozen. Direct colorimetric determination of the copper, zinc and iron concentrations without deproteination in the plasma was conducted on the apparatus Konelab T 20 xt (THERMO ELECTRON OY, Finland).

During the last five days of the experiment (after 9 days of supplementation with various copper sources) samples of the faeces were taken, approximately $200 \mathrm{~g} /$ day. After drying up the samples were prepared and the contents of trace elements were assessed using atomic absorption spectrometry. A homogeneous sample charge of $0.5 \mathrm{~g}$ was mineralized in the mixture of concentrated nitric acid and hydrogen peroxide in the ETHOS 1 microwave system (MILESTONE, Italy). After the sample decomposition, the solution of demineralised water was added to achieve the volume of $25 \mathrm{ml}$. The concentration of elements in solutions prepared this way was established on the atomic absorption spectrometer with a continual radiation source of high resolution Model Contr AA 700 (ANALYTIC JENA, Germany). Wavelengths used were as follows: Zn $213.857 \mathrm{~nm}$, Fe $248.327 \mathrm{~nm}$ and $\mathrm{Cu} 324.754 \mathrm{~nm}$.

Samples of hair were taken to assess the content of deposited trace elements. On the first day of the experiment, a piece of mane hair was removed from the nape in horses and the trial samples were obtained from the same place after experimental periods (14 days). The samples of hair were rinsed in water containing a degreasing preparation and then repeatedly rinsed in demineralised water, dried and prepared for analyses. The content of the individual trace elements was also assessed using the method of atomic absorption spectrometry.

The basic statistical parameters of the set of results (mean, standard deviation) obtained from the individual groups and their statistical comparisons were processed in Microsoft Excel. The results were statistically assessed using Student's t-test for pair and unpaired samples. The correlations and regression analyses of associated values in various biological materials were also performed in Microsoft Excel.

\section{RESULTS}

The average initial ( $1^{\text {st }}$ day) and final ( $14^{\text {th }}$ day) level of monitored elements in the blood plasma of horses, their standard deviations and statistical dependences are presented in Tab. III. The initial samplings did not show any significant difference between the groups in any of the monitored parameters. The results show that the intervention into the feeding rations of mares resulted in a significant difference $(\mathrm{P}<0.05)$ in the plasma contents of $\mathrm{Cu}$ and $\mathrm{Fe}$ between the mares receiving various forms of copper. The levels of the other elements did not change.

The object of interest was also the evaluation of hair as an indicator of the trace elements status (Tab. IV). The copper content increased significantly $(\mathrm{P}<0.01)$ in mares supplemented with copper 
III: Statistical evaluation (Student pairt-test) of changes in the level of monitored elements in the blood plasma of horses (mean $\pm S_{x}$ )

\begin{tabular}{|c|c|c|c|c|}
\hline \multirow[b]{2}{*}{ Group } & \multirow[b]{2}{*}{ Taking } & \multicolumn{3}{|c|}{ Plasma parameters } \\
\hline & & $\begin{array}{c}\mathrm{Cu} \\
\left(\mathrm{mg} \cdot \mathrm{kg}^{-1}\right)\end{array}$ & $\begin{array}{c}\mathrm{Zn} \\
\left(\mathrm{mg} \cdot \mathrm{kg}^{-1}\right)\end{array}$ & $\begin{array}{c}\text { Fe } \\
\left(\mathrm{mg}^{-k^{-1}}\right)\end{array}$ \\
\hline \multirow{2}{*}{$\begin{array}{l}\text { Organic form } \mathrm{Cu} \\
(\mathrm{n}=7)\end{array}$} & $1^{\text {st }}$ day & $0.96 \pm 0.11$ & $0.58 \pm 0.04$ & $1.13 \pm 0.24$ \\
\hline & $14^{\text {th }}$ day & $0.93 \pm 0.13$ & $0.64 \pm 0.11$ & $1.55 \pm 0.25^{\mathrm{x}}$ \\
\hline \multirow{2}{*}{$\begin{array}{l}\text { Inorganic form } \mathrm{Cu} \\
(\mathrm{n}=7)\end{array}$} & $1^{\text {st }}$ day & $0.87 \pm 0.11$ & $0.56 \pm 0.06$ & $1.52 \pm 0.45$ \\
\hline & $14^{\text {th }}$ day & $0.78 \pm 0.08^{\mathrm{x}}$ & $0.57 \pm 0.07$ & $1.28 \pm 0.17$ \\
\hline \multirow{2}{*}{$\begin{array}{l}\text { Control } \\
(\mathrm{n}=6)\end{array}$} & $1^{\text {st }}$ day & $0.95 \pm 0.11$ & $0.53 \pm 0.04$ & $1.33 \pm 0.14$ \\
\hline & $14^{\text {th }}$ day & $0.86 \pm 0.14$ & $0.59 \pm 0.05$ & $1.52 \pm 0.38$ \\
\hline
\end{tabular}

Changes between the samplings were in terms of groups and individual parameters: $x$ significant $(\mathrm{P}<0.05)$

IV: Statistical evaluation (Student unpairt-test) of the trace elements in the dry matter of hair, faeces and plasma of horses after a supplement of a different copper sources (mean $\pm S_{x}$ )

\begin{tabular}{|c|c|c|c|c|}
\hline & & Organic $\mathrm{Cu}(\mathrm{n}=7)$ & Inorganic $\mathbf{C u}(\mathrm{n}=7)$ & Control $(n=6)$ \\
\hline \multirow{3}{*}{$\begin{array}{l}\text { Hair } \\
\left(\mathrm{mg} \mathrm{kg}^{-1}\right)\end{array}$} & $\mathrm{Zn}$ & $153.41 \pm 41.058^{\mathrm{a}}$ & $178.73 \pm 19.419^{a}$ & $168.25 \pm 26.139^{a}$ \\
\hline & $\mathrm{Cu}$ & $15.32 \pm 1.129^{\mathrm{AB}}$ & $17.39 \pm 2.322^{\mathrm{B}}$ & $13.46 \pm 1.974^{\mathrm{A}}$ \\
\hline & $\mathrm{Fe}$ & $93.32 \pm 60.848^{b}$ & $258.75 \pm 179.360^{a}$ & $202.86 \pm 112.036^{\mathrm{ab}}$ \\
\hline \multirow{3}{*}{$\begin{array}{l}\text { Faeces } \\
\left(\mathrm{mg} \cdot \mathrm{kg}^{-1}\right)\end{array}$} & $\mathrm{Zn}$ & $41.58 \pm 1.450^{\mathrm{aA}}$ & $45.56 \pm 2.299^{B}$ & $52.89 \pm 9.911^{b}$ \\
\hline & $\mathrm{Cu}$ & $11.57 \pm 0.899^{\mathrm{B}}$ & $12.10 \pm 1.232^{\mathrm{B}}$ & $8.28 \pm 0.682^{A}$ \\
\hline & $\mathrm{Fe}$ & $822.83 \pm 321.968^{a}$ & $1302.04 \pm 364.114^{b}$ & $1025.12 \pm 144.623^{\mathrm{ab}}$ \\
\hline \multirow{3}{*}{$\begin{array}{l}\text { Plasma } \\
\left(\mathrm{mg}^{\prime} \mathrm{kg}^{-1}\right)\end{array}$} & $\mathrm{Zn}$ & $0.64 \pm 0.11$ & $0.57 \pm 0.07$ & $0.59 \pm 0.05$ \\
\hline & $\mathrm{Cu}$ & $0.93 \pm 0.13^{a}$ & $0.78 \pm 0.08^{b}$ & $0.86 \pm 0.14^{a b}$ \\
\hline & $\mathrm{Fe}$ & $1.55 \pm 0.25^{\mathrm{a}}$ & $1.28 \pm 0.17^{b}$ & $1.52 \pm 0.38^{\mathrm{ab}}$ \\
\hline
\end{tabular}

Differences between the groups within the framework of the individual elements were as follows: abc - significant $(\mathrm{P}<0.05) ; \mathrm{ABC}-\operatorname{significant}(\mathrm{P}<0.01)$

sulphate as compared to mares in control group. Even though the level of copper in the mane hair of mares receiving Bioplex-Cu increased considerably, compared to mares of the control group this increase was not statistically significant. The levels of zinc in the mane hair did not differ among individual groups.

Low iron levels in hair of mares receiving copper in organic form unrelated only with metabolism of copper but also with conditions of kept. Highly significant differences $(\mathrm{P}<0.001)$ were found between the mares with and without an access to paddock (Fig. 1). Hair concentrations of copper and zinc between the mares with different conditions of kept did not differ.

The aim of our experiment was also to find out how the application of various sources of copper affects her concentration and levels of other trace elements in the horse faeces (Tab. IV). The results indicate that intervention into the feed rations of

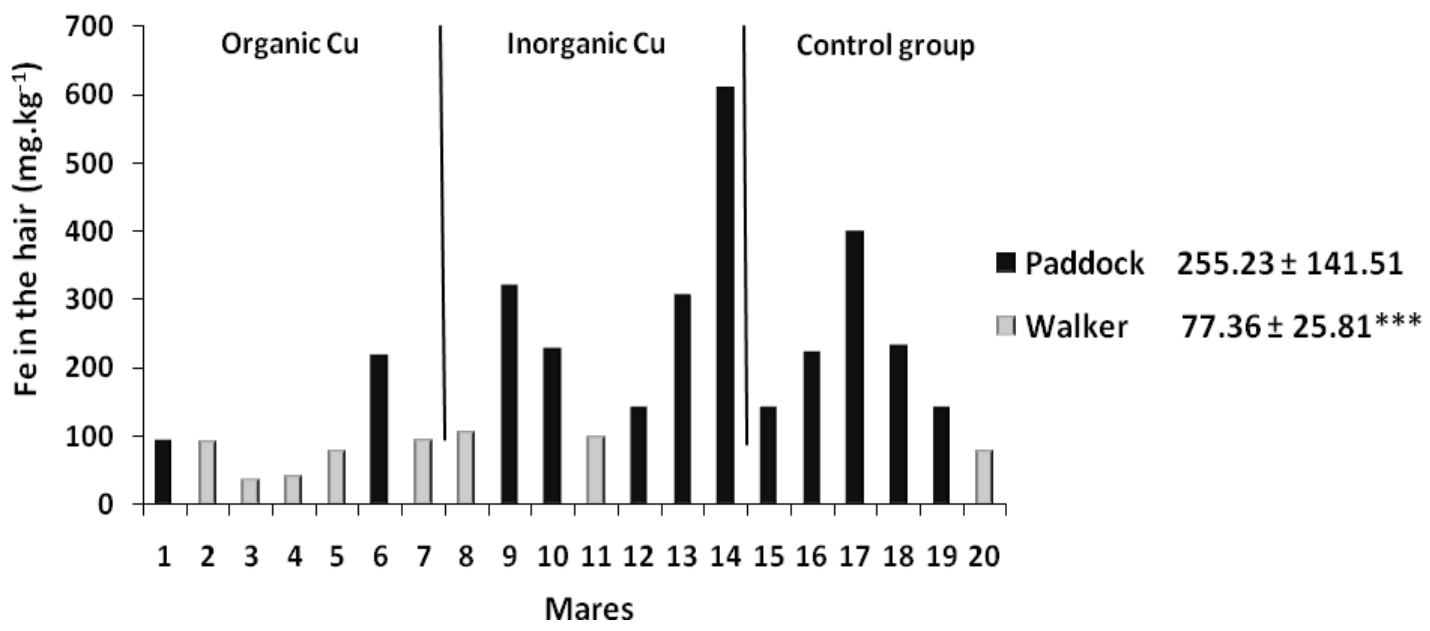

1: The level of iron $\left(\mathrm{mg}_{\mathrm{g}} \mathrm{kg}^{-1}\right)$ in the dry matter of mane hair (mean $\left.\pm S_{x}\right)$ in the mares with different condition of $k e p t\left(\right.$ mean $\left.\pm S_{x}\right)$ 


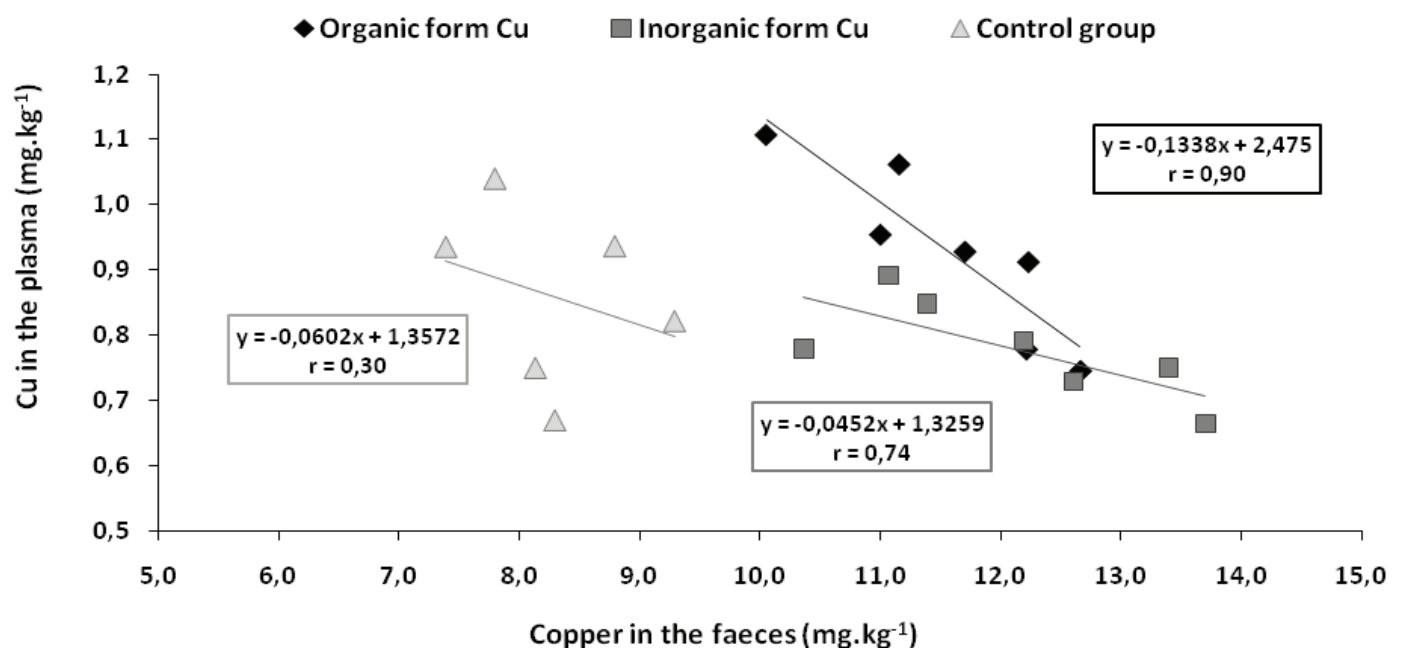

2: Correlation between the level of copper in the blood plasma and its concentration in the faeces

mares in the experimental groups significantly increased $(\mathrm{P}<0.01)$ the content of copper in excrements. The zinc content in mares of the experimental groups was lower than in mares of the control group; however the difference was statistically significant $(\mathrm{P}<0.05)$ only between the control group and mares with addition Bioplex-Cu. Significant differences were also found out in the contents of zinc $(\mathrm{P}<0.01)$ and iron $(\mathrm{P}<0.05)$ between mares of the experimental groups.

We evaluated the correlation between the level of $\mathrm{Cu}$ in blood plasma and the concentration of copper in the excrements (Fig. 2). In the group of mares receiving Bioplex- $\mathrm{Cu}(\mathrm{r}=-0.90)$ the content of copper in the faeces increased highly significantly $(\mathrm{P}<0.01)$ with decreasing concentration of copper in the blood plasma; in mares receiving the inorganic form of copper $(\mathrm{r}=-0.74)$ this correlation was conclusive at the level of 0.05 significance and in mares of the control group $(r=-0.30)$ the correlation between these variables was not detected.

We also evaluated the correlation between the level of copper in the blood plasma and its amount deposited in the hair of the mares and between the content of copper in hair and its concentration in the faeces. The correlations among these variables were not significant.

\section{DISCUSSION}

The animals are capable of accumulating an oversupply of copper in the liver and thus maintaining the concentration of blood copper within a normal range. Consequently, monitoring serum copper concentration to determine copper toxicosis is not recommended (Herdt and Hoff, 2011). Also Ott and Asquith (1995) found no effect of different copper levels in the diet on the copper plasma levels. Naile et al. (2005) supplemented the feed rations of yearlings with copper sulphate and $\mathrm{Cu}$-plex which resulted in a significant increase ( $\mathrm{P}$ $<0.05)$ its level in the serum of horses fed the organic form in comparison to horses supplemented with sulphate. This trend however was discovered in only one of the 3 periods of the trial. Pal et al. (2010) reported higher plasma levels of $\mathrm{Cu}$ and $\mathrm{Zn}$ when organic forms of these trace elements were used. Wagner et al. (2010) found no effect of source on the serum concentration of either $\mathrm{Cu}$ or $\mathrm{Zn}$ in yearling horses. Brommer and Sloet van OldruitenborghOosterbaan (2001) reported that blood iron concentrations were lower $(\mathrm{P}<0.05)$ in the two boxstalled groups as compared to the pastured group. Plasma iron levels in our experiment were not differed between mares with access to the paddock or walker. Copper is essential for mobilization of iron stores (NRC, 2007); higher activity of organic form of copper in the organism may be reason elevation the content of Fe in the plasma in the mares with supplement Bioplex-Cu. The blood plasma is not a suitable indicator of the mineral status of the animals; the levels of blood copper of the mares in experimental groups did not differ from the control group but may be an indicator of copper activity in the organism which was significantly higher in mares receiving bioplex $(\mathrm{P}<0.05)$ than in the mares receiving copper sulphate (Tab. IV).

According to Biricik et al. (2005) the serum and hair copper concentrations did not reflect the copper levels used in diet. Jacob et al. (1978) discovered a positive correlation between copper intake and its level in rat hair. O'Mary et al. (1970) likewise concluded that the level of $\mathrm{Cu}$ in the diet had an effect on the $\mathrm{Cu}$ concentration in the hair of cattle. The content of copper in the mane hair reflected increasing diet amount of copper in our experiment. The mineral content of mares hair apparently varied not only with mineral intake, but also with the condition of kept. Brommer and Sloet van Oldruitenborgh-Oosterbaan (2001) reported that an absolute deficit of body iron may occur in stabled foals. The authors concluded that soil from the pasture was an important source of iron, since all 
foals were eating the same grass and only the pasture group had access to soil. In our study also deposited the mares with the access to paddock (access to soil) more iron in the dry matter of mane hair than mares without this option (Fig. 1).

Wagner et al. (2005) did not detect a significant difference in the absorption of copper and zinc when their oxide, sulphate and organic-chelate forms were fed. Naile et al. (2005) also used various forms of copper and from their results it is evident that in two of the three periods the excretion of the organic form of copper in the excrements was significantly higher $(\mathrm{P}<0.05)$ than of the inorganic form of copper. Feeding of $\mathrm{Cu}$ and $\mathrm{Zn}$ from methionine-chelated source resulted in reduced excretion of $\mathrm{Cu}$ and $\mathrm{Zn}$ in faeces indicating their better utilization ( $\mathrm{Pal}$ et al., 2010). Mondal et al. (2007) also reported lower excretion of $\mathrm{Cu}$ through $\mathrm{Cu}$-proteinate as compared to $\mathrm{CuSO}_{4}$. Wagner et al. (2011) reached the conclusion that when horses were supplemented with organic and inorganic forms of $\mathrm{Cu}$ and $\mathrm{Zn}$ the concentration of these elements in the faeces increased. Faecal mineral excretion for the groups reflected the disparity in mineral intake. Apparent $\mathrm{Cu}$ absorption as a percentage of intake and retention as a percentage of intake seemed to be greater when the horses consumed organic form of $\mathrm{Cu}$ compared with the sulphate form. In our experiment the absorption of copper was slightly less effective in mares receiving the inorganic form of copper and the concentrations of copper in the faeces reflected increasing amount of copper in the diet. An excessive amount of copper evidently reduced the absorption of zinc and iron; mineral substances which have a similar form (Herdt and Hoff, 2011). The absorption of zinc and iron were the most affected in mares with addition of copper sulphate.

\section{CONCLUSION}

The results show that the intervention into the feeding rations of mares resulted in a significant difference $(\mathrm{P}<0.05)$ in the plasma contents of $\mathrm{Cu}$ between the mares receiving various forms of copper. Copper hair content increased significantly $(\mathrm{P}<0.01)$ in the mares received inorganic form of $\mathrm{Cu}$ and in both of the groups with $\mathrm{Cu}$ addition increased significantly $(\mathrm{P}<0.01)$ the content of copper in excrements.

The mares receiving Bioplex-Cu excreted lower amount of copper in the faeces. These had wellbalanced levels of $\mathrm{Cu}$ in the plasma and deposited less $\mathrm{Cu}$ in the hair than the mares with addition of copper sulphate. In our experiment, it seems to be better available copper in the organic form than in the inorganic form for the organism of horses.

\section{SUMMARY}

The purpose of our work was to assess the effect of various copper sources on the trace elements profile in the hair, plasma and faeces and copper activity in the organism of horses.

The 20 healthy mares were divided into three groups and subjected to different mineral feeding modes. All mares received the same basic feed ration that was supplemented with various form of copper ( $\mathrm{Cu}$ in the organic form - proteinate - Bioplex Cu vs. $\mathrm{Cu}$ in the inorganic form - $\mathrm{CuSO}_{4} .5 \mathrm{H}_{2} \mathrm{O}$ ) in amount of $120 \mathrm{mg}$ per day for the mares in experimental groups. The mares in the control group received grain feed without the $\mathrm{Cu}$ enrichment. The contents of trace elements in hair and faeces were established using the atomic absorption spectrometry; in the plasma using direct colorimetric determination.

Significant difference between mares receiving copper in organic and inorganic form $(\mathrm{P}<0.05)$ was detected in the blood levels of copper and iron. In both experimental groups a supplement of copper increased its level in the hair as compared to the control group; however this increase was statistically significant $(\mathrm{P}<0.01)$ only if the inorganic form of copper was supplemented. The iron content of mares hair apparently varied not only with minerals intake, but also with the condition of kept. The differences of copper concentration in the faeces among the mares of experimental groups with regard to control group were significant $(\mathrm{P}<0.01)$. An excessive amount of copper evidently reduced the absorption of zinc and iron in mares with addition of copper sulphate. The absorption of copper was less effective in mares receiving the inorganic form of copper. In this group the level of copper in the blood plasma was the lowest, the amount excreted in the excrements the highest and the mares deposited the highest amount of copper in the hair. In contrast, the amount of copper excreted by mares receiving the organic form was lower, the blood level was higher and the content in hair was lower than in mares receiving copper sulphate. In our experiment, it seems to be better available copper through Cu-proteinate as compared to sulphate. At lower doses of copper in the diets of mares in the control group was to ensured optimal plasma levels of copper in the organism using higher absorption, lower concentrations of copper excreted in the faeces and a lower deposition of copper in mane hair.

Nevertheless, interpretation of these results is very difficult. Evaluation the impact of various sources of copper on the elements profile; assessed using skin derivates, plasma or other parameters should be subjected to further observation. 
Acknowledgement

This project was funded from IGA AF MENDELU Grant No. TP 2/2011 and TP 3/2012.

\section{REFERENCES}

BIRICIK, H., OCAL, N., GUCUS, A. I., EDIZ, B., UZMAN, M., 2005: Seasonal Changes of Some Mineral Status in Mares. J. Equine Vet. Sci., 25: 346348.

BROMMER, H., SLOET VAN OLDRUITENBORGHOOSTERBAAN, M. M., 2001: Iron deficiency in stabled Dutch warmblood foals. J. Vet. Intern. Med., 15: 482-485.

COMBS, D. K., 1987: Hair Analysis as an Indicator of Mineral Status of Livestock. J. Anim. Sci., 65: 17531758.

COMBS, D. K., GOODRICH, R. D., MEISKE, J. C., 1982: Mineral Concentrations in Hair as Indicators of Mineral Status: a Review. J. Anim. Sci., 54: 391398.

DUNNETT, M., LEES, P., 2003: Trace element, toxin and drug elimination in hair with particular reference to the horse. Res. Vet. Sci., 75: 89-101.

GABRYSZUK, M., SLONIEWSKI, K., METERA, E., SAKOWSKI, T., 2010: Content of Mineral Elements in Milk and Hair of Cows from Organic Farms. J. Elementol., 15(2): 259-267.

HERDT, T. H., HOFF, B., 2011: The Use of Blood Analysis to Evaluate Trace Mineral Status in Ruminant. Vet. Clin. North Am. Small Anim. Pract., 27: 255-283.

HINTZ, H.F., 2001: Hair as an Indicator of Nutritional Status. J. Equine Vet. Sci., 21: 199.

HOYT, J. K., POTTER, G. D., GREENE, L. W., ANDERSON, J. G., 1995: Copper Balance in Miniature Horses Fed Varying Amounts of Zinc. J. Equine Vet. Sci., 15: 357-359.

JACOB, R. A., KLEVAY, L. M., LOGAN, G. M., 1978: Hair as a biopsy material: V. Hair metal as an index of hepatic metal in rats: copper and zinc. Am. J. Clin. Nutr., 31: 477-480.

LOWE, N. M., FEKETE, K., DECSI, T., 2009: Methods of assessment of zinc status in humans: a systematic review. Am. J. Clin. Nutr., 89: 2040-2051.

MONDAL,M.K.,BISWAS, P., ROY,B.,MAZUMDAR, D., 2007: Effect of copper sources and levels on serum lipid profiles in Black Bengal (Capra hircus) kids diet. Small Rum. Res., 67: 28-35.

NAILE, T. L., COOPER, S. R., FREEMAN, D. W., KREHBIEL, C. R., 2005: Effect of Mineral Source on Growth and Balance in Yearling Horses. Prof. Anim. Sci., 21: 121-127.
NATIONAL RESEARCH COUNCIL, 2007: Nutrient requirements of horses. The National Academies Press. Washington, D.C., pp. 341.

O'MARY, C. C., BELL, M. C., SNEED, N. N., BUTTS, W. T., 1970: Influence of Ration Copper on Mineral in the Hair of Hereford and Holstein Calves. J. Anim. Sci., 31: 626-630.

OTT, E. A., ASQUITH, R. L. Trace mineral supplementation of yearling horses. J. Anim. Sci., 1995, 73: 466-471.

PAGAN, J. D., 2001: Micromineral requirements in horses. In: PAGAN, J. D; GEOR, R. J. Advances in Equine Nutrition II. 1. Kentucky Equine Research Inc.: Nottingham University Press, s. 317-327. ISBN 1-897676-78-6.

PAL, D. T., GOWDA, N. K. S., PRASAD, C. S., AMARNATH, R., BHARADWAJ, U., SURESH BABU, G., SAMPATH, K. T., 2010: Effect of copper- and zinc-methionine supplementation on bioavailability, mineral status and tissue concentrations of copper and zinc in ewes. J. Trace Elem. Med. and Biology, 24: 89-84.

SCHRYVER, H. F., HINTZ, H. F., LOWE, J. E., 1980: Absorption, excretion and tissue distribution of stable zinc and 65zinc in ponies. J. Anim. Sci., 51: 896-902.

WAGNER, E. L., POTTER, G. D., ELLER, E. M., GIBBS, P. G., HOOD, D. M., 2005: Absorption and Retention of Trace Minerals in Adult Horses. Prof. Anim. Sci., 21: 207-211.

WAGNER, E. L., POTTER, G. D., GIBBS, P. G., ELLER, E. M., SCOTT, B. D., VOGELSANG, M. M., WALZEM, R. L., 2011: Copper and Zinc balance in exercising horses fed 2 forms of mineral supplements. J. Anim. Sci., 89: 722-728.

WAGNER, E. L., POTTER, G. D., GIBBS, P. G., ELLER, E. M., SCOTT, B. D., VOGELSANG, M. M., WALZEM, R. L., 2010: Copper, Zinc-Superoxide Dismutase Activity in Exercising Horses Fed Two Forms of Trace Mineral Supplements. J. Equine Vet. Sci., 30: 31-37.

WAPNIR, R. A., 1998: Copper absorption and bioavailability. Am. J. Clin. Nutr., 67: 1054S-60S.

WELLS, L. A., LEROY, R., RALSTON, S. L., 1990: Mineral Intake and Hair Analysis of Horses in Arizona. Equine Vet. Sci., 10: 412-416.

Ing. Petra Jančíková, Ing. Pavel Horký, prof. Ing. Ladislav Zeman, CSc., Ústav výživy zvířat a pícninářství, Mendelova univerzita v Brně, Zemědělská 1, 61300 Brno, Česká republika, e-mail: petra.jancikova@ mendelu.cz 
